\title{
Is AIDS a just punishment?
}

\author{
Timothy F Murphy Center for Educational Development, University of Illinois at Chicago, USA
}

\section{Author's abstract}

There are religious and philosophical versions of the thesis that AIDS is a punishment for homosexual behaviour. It is argued here that the religious version is seriously incomplete. Because of this incompleteness and because of the indeterminacies that ordinarily attend religious argumentation, it is concluded that the claim may be set aside as unconvincing. Homosexual behaviour is then judged for its morality against utilitarian, deontological, and natural law theories of ethics. It is argued that such behaviour involves no impediment to important moral goals and is not therefore immoral. Where natural law might be used to condemn homosexual behaviour, it is argued that the theory itself is not well established. Consequently there is a prima facie reason for rejecting the philosophical version of the punishment thesis. This conclusion is further supported by noting the lack of proportion between the purported immorality of homosexuality and a punishment as devastating as AIDS.

If any man lie with a man as with a woman, both have committed an abomination, let them be put to death: their blood be upon them.

Leviticus 20:13

One of the meanings of punishment is harm deserved as the result of evil done. According to a belief persistently bruited about, often by Christian theists, the disabilities and death associated with AIDS are a fitting punishment for certain immoral behaviours. According to this belief, sexual and other immoralities such as narcotic drug use open one up to disease properly understood as a just punishment. Depending on the perspective involved, the moral enforcer may either be divinity or nature. In this essay I review the thesis that AIDS is indeed a just punishment for immoral behaviour. Although there are various versions of this thesis, I confine the discussion here to punishment of homosexual behaviour. I will contend that because religious arguments do not meet the burden of proof and because moral arguments fail to show either the immorality of homosexuality or the

\section{Key words}

AIDS; homosexuality; punishment. parity between crime and punishment that the punishment notion of AIDS is intellectually indefensible and entirely counterproductive in attempting to understand and control the disease.

\section{Wrongful behaviour}

Behaviour is wrongful when it is inappropriate to or incompatible with some stipulated goal or norm. Wrongful behaviour may be the result of accident, inattention, inability, or direct volition. Not all wrongful behaviour constitutes a moral wrong. One can, for example, be wrong in the way one plays a game without being morally culpable. Moral behaviour pertains to persons as such, to those goals and goods associated with the dignity and worth of human life. Immoral behaviour is that which breaches the prospects for achieving those goals and goods.

In view of these distinctions, not all wrongs are of equal evil. Some acts are evil only within the context of a particular, elective goal. Thus, for example, hockey players are sent to the penalty box and not the electric chair for their infractions. Neither is anyone incarcerated for failing to develop his or her artistic talents. Other acts are evil insofar as they abandon or destroy singularly valuable human goods. Thus, for example, is genocide wrong. As there is a continuum of wrongful behaviour, so too must there be a continuum of appropriate punishment. Punishment is just and defensible only as it is proportional to the severity of any particular wrongdoing. The following table suggests various degrees of wrongdoing and the degrees of punishment that would be appropriate to each.

Because there are so many levels of wrongdoing, it is important to pay attention to the way in which an evil is punished. Therefore, in this essay, it will be necessary to determine not only if homosexual behaviour is an immorality but also how serious an immorality it might be. As AIDS is a gravely disabling and lethal disease, one would expect, according to the punishment thesis, that homosexuality is a grave immorality, otherwise the proportionality required by justice is absent. If the punishment does not fit the crime, an even greater immorality may be at work.

\section{Sexual immorality}

Objections to homosexual behaviour are often a- 


\section{Wrongful behaviour}

Potential wasted and opportunities lost

Rude and tasteless behaviour

Unintentional harm to another)
a. slightly injurious
b. grossly incapacitating
c. assaults on dignity
d. killing

Intentional harm to another

a. slightly injurious

b. grossly incapacitating

c. assaults on dignity

d. killing

\section{Appropriate punishment}

Lack of access to the rewards of opportunities realised and potential realised

Exclusions from certain areas or functions or shunnings by particular persons

Punishments in these two categories graduated according to degree of responsibility, degree of injury, and any inherently objectionable aspects of wrongdoing theoretical; that is they proceed from unfamiliarity, pre-existing bias, or some other purely psychological response. Nevertheless, there are numerous theoretical arguments which purport to establish the immorality of homosexual behaviour, arguments both religious and philosophical in kind. Here I will review a standard religious objection to homosexual behaviour for its relevance to the punishment thesis. Secondly, I will test homosexuality against standard ethical canons to see what immorality can be attributed to it.

\section{RELIGIOUS ARGUMENTS}

Homosexual behaviour is often said to be a violation of divine will for human beings, conformity to which is the supreme good. In Christianity, biblical support is claimed for this view. The Old Testament explicitly names sexual acts between men as an abomination punishable by death (Leviticus 18:22 and 20:13). While the gospels themselves are silent on the topic of homosexuality, in his letters Paul at least three times condemns homosexuality as wrong (1 Corinthians 6:10, 1 Romans 1:24-27, 1 Timothy 1:10). These passages, moreover, are generally interpreted in the context of other scriptural passages said to reinforce the wrongfulness of homosexuality. Scripture is variously said to praise the rewards of heterosexuality and establish a fixedness to the relations between the sexes. Thus did the Roman Catholic Church recently condemn homosexuality both as an orientation and a behaviour: 'To choose someone of the same sex for one's sexual activity is to annul the rich symbolism and meaning, not to mention the goals, of the Creator's sexual design. Homosexual activity is not a complementary union, able to transmit life; and so it thwarts the call to a life of that form of self-giving which the Gospel says is the essence of Christian living . . . homosexual activity prevents one's own fulfilment and happiness by acting contrary to the creative wisdom of God' (1).
It is not surprising therefore that many persons who $\frac{\mathbb{D}}{\mathbb{D}}$ invoke the punishment thesis of AIDS do so from a 3 Christian perspective. Moral Majority leader $\mathrm{Cal} \underset{\mathbb{\Phi}}{\overparen{D}}$ Thomas has made it clear that he believes that were there no homosexuality, there would be no AIDS (Z2. Veronica Leuken, a housewife in Bayside, New Yore,, claims frequent visitations from Jesus. In one su해응 visit, she says, Jesus told her: 'Homosexuality shạ never be accepted. In the writings of the good Fathers, My child and My children, you were made fully aware in the Old and New Testament of the Book of life and $\stackrel{\mathbb{Q}}{\complement}$ love, the Bible - you have been made fully aware of the $\overrightarrow{\overrightarrow{.}}$ dastardly acts of mankind as men consort with men. $\frac{3}{3}$ This shall not be accepted or condoned by the Eternal Father even if $\mathrm{He}$ has to send another plague upon you'? (3). Any number of clerics have made similar claims: Jerry Falwell ("AIDS is the wrath of God upon homosexuals'); Charles Stanley, president of the American Southern Baptist Convention ('AIDS is God픔. indicating his displeasure toward a sinful lifestyle.'), $\varrho$ and the Anglican Dean of Sydney, Australia ('Gays $₹$ have blood on their hands') (4). Even persons with AIDS have seen their suffering as a consequence of $\supset$ their sins. In 1985, for example, Paul Brummett, a을. twenty-two-year-old native of Dayton, Ohio, found $\bar{N}$ himself in the AIDS ward of the San Francisco General ${ }^{\circ}$ Hospital. 'God struck me down,' he said. 'He said he'd N damn me to hell for all eternity if I didn't live and praise ${ }_{\mathcal{W}}^{N}$ his holy name. I rebelled against my parents. I foundo all kinds of bad things out there [in San Francisco]. Io met the wrong crowd, started going out to bars, $\frac{\mathbb{\Phi}}{2}$ drinkings, and talking dirty' (5).

If AIDS is a punishment from god, by extension, its 0 'cure' consists in the repudiation of sinfulness and

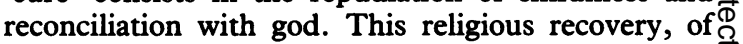
course, may or may not end in bodily recovery. The $\stackrel{\mathbb{Q}}{\mathscr{Q}}$ prevention of AIDS, similarly, consists in refraining from jeopardising homosexual behaviour not as a 
matter of prudence but as a matter of religious imperative. On an optimistic religious view, a return to monogamous heterosexual relations in marriage would considerably diminish the incidence of AIDS.

The thesis that AIDS is a divine punishment for wrongful sexual behaviour is a difficult one to evaluate, involving as it does claims about god and his will. Here I will establish not that god does or does not exist but what premises would have to be substantiated in order to make the punishment thesis credible (even to a theist). As will be seen, there is a considerable burden of proof to be shouldered.

A. On the existence of god. To be sure, the divine punishment theory of AIDS goes nowhere unless god exists. It needs to be established therefore that god does indeed exist. As important is the issue of god's will for human beings. Even if there is a god it does not follow that he is particularly interested in human beings. He may be indifferent to the fate of human beings or may want them to conduct their lives according to their own lights. It is necessary therefore to establish that god does indeed have a will relevant to the shaping of our moral judgements. The concerns here are primarily epistemological: How do we know there is a deity who has a will for us? What kind of evidence is relevant? How do we decide between competing claims? For many persons these questions are decidable in favour of a theistic hypothesis. It is, however, false to say that the theistic hypothesis is the only credible hypothesis. As a result, the basic premise of the punishment thesis is open to question.

B. Interpreting the will of god. For the sake of the argument we may assume that there is indeed a god who does have a will relevant to our sexual behaviour. Nevertheless, the interpretation of that will seems to me at least as difficult as finding out whether or not there is a god. How do we know god's will? Do we wait for mystic enlightenment? Do we rely on empirical and historical evidence? Do we rely on intuitions? Suppose we take it as fact that god's will is expressed in the bible. What follows? Is that document to be taken as a literal or metaphorical guide to moral conduct? Involved in any textual interpretation are problems of authenticity, transmission, completeness, translation, relevance, and comprehension. The passages in Leviticus condemning homosexual behaviour are surrounded by other condemnations, made with equal force, that are routinely ignored and written off as outdated ritual observance. What is cultural idiom and what is universal truth? Paul's commentary notwithstanding, the gospels themselves are silent on the subject of homosexuality. What is text and what is accretion? Exegetical problems, it seems to me, pose difficulties of the first order in determining what is and what is not god's will. People of good will and untarnished intellect have looked at the same book and come away with different moral interpretations. How is this possible except to say that the will of God is not unequivocally clear even in the text it is supposed to inhabit? No one really believes that it was the sun itself which stopped in its orbit when Joshua bade it stop. Isn't it possible that the authors of Leviticus and Paul himself speak from an outdated moral cosmology as well? At the very least, it seems to me, proving the immorality of homosexuality, by claiming that it is a violation of God's will, has to consist of more than mere recitation of chapter and verse.

C. Selective enforcement. Even if it were shown that god did unequivocally condemn homosexual behaviour, one still rightly wonders why he has singled out homosexuality for punishment. Why, for example, are idolators, adulterers, and fornicators not similarly struck down (1 Corinthians 6:9-10)? Why are murderers and uncharitable persons not stricken with punishing diseases? Jesus himself explicitly condemns divorce (Mark 10:2-12). Why is there no plague of divorcees? The concern here is that in punishing only some persons for their sins, punishment is arbitrary and for that reason unjust. Such a concern is heightened by a further consideration. It is, after all, only a minority of homosexual persons who have been stricken with AIDS. Even if the highest projections on the incidence of AIDS are correct, still only a minority of the many millions of homosexual persons in the United States and elsewhere have either been stricken or are infected with the presumptive viral cause. Why, too, in punishing (some) male homosexuals has god refrained from punishing any female homosexuals? Why is male homosexuality any more heinous than female homosexuality? Why, moreover, has god waited so long to punish homosexual behaviour? Homosexual behaviour has a long pedigree and is found in disparate cultures. Why has god waited until now to punish only a few persons out of the many millions who have committed and continue to commit homosexual sins? It is not my point here that there are no answers to these questions. It is my contention, though, that only when they are answered is it possible to maintain the punishment thesis of AIDS.

D. Exacting retribution. AIDS is a gravely disabling disease involving prolific cancerous lesions, life-threatening pneumonia, dementia, drastic weight loss, diarrhoea, fevers, and bacterial infections, among the most commonly reported disruptions. The question arises, therefore, why homosexual behaviour must be punished so severely. Among adults, homosexual behaviour is ordinarily voluntary and victimless. It leaves behind no bodies as murder does. It involves no betrayal of spouses as adultery does (unless an individual is married). Its carnal desires are seemingly no more fleshy than heterosexual desires. Its excesses are not unlike those documented in heterosexual pornography. Its sterility is elsewhere precedented in the contraceptive uses of married and unmarried heterosexuals. Homosexuality, qua erotic desire, seems not at all to jeopardise society's existence or ideals. Why, then, is homosexuality so bad, apart from all similar kinds of wrongs, that god must rush into this life and begin his terrible punishment here? Why can't he wait for Judgement Day? Why isn't 
eternity time enough for punishment? If AIDS as a punishment of homosexuality is to be understood as anything but an idiosyncratic indulgence in selective enforcement and uncontrolled vengeance, we need to know why homosexuality is such an evil that it deserves the tragic destiny of AIDS. How, in other words, is the punishment not a more vicious immorality than the crime?

E. Other religious views. Not all religious views see homosexuality as an immorality. This is true even of some Christian interpretations. Not all religious views require disease to be seen as the result of god's direct intervention against sinful behaviour. Some early Christians, for example, saw diseases as the result of demonic influence (6). It was not god who was punishing, under such a view, but demons who were torturing. Such a view attributed to god the role of protector and healer.

Some religious interpretations continue to attribute to god the role of healer and require of believers an active sympathy for ill persons. The New Testament, for example, is full of exhortations to compassion, pity, and self-sacrifice. The example of the Good Samaritan is instructive on this point (Luke 10:30-37). When the Samaritan stopped to help his wounded neighbour, he did all he could do to help. As there were no major medical centres available, in washing the man's wounds, binding them up, transporting the man to an inn where he could stay, pre-paid, while recuperating, there was nothing the Samaritan left undone. Similarly, to understand Jesus as dying for the sins of human beings is to understand him as doing all that he could. Even if one wants to understand AIDS, therefore, as a punishment from god, it does not follow that we may ourselves contribute to that punishment, as Loretta Kopelman has pointed out (7). If anything, the reverse is true. There is considerable religious evidence that persons ought to care for suffering persons and to do so no matter the origin of their disabilities. There are no biblical injunctions to punish where and how god has punished. If the New Testament is any measure, religious believers are bound to charity towards AIDS sufferers. The moral significance of AIDS, therefore, resides not (only) in its being (arguably) a divine punishment but (even most importantly) in its being an occasion of charity.

I do not pretend to know if there is a god or what his will for human beings might be. But I can say that if AIDS is to be understood as a divine punishment for wrongful sexual behaviour, the following need to be established: that there is a god; that his will forbids homosexual behaviour; that it is just to punish this behaviour while not punishing other wrongful acts, and that the transgression is of such a kind to justify the extraordinarily harsh punishment of AIDS.

Most usages of the punishment theory of AIDS do not offer anything like a full defence of the position, let alone a credible defence. I conclude therefore that the argument is, at best, inconclusive. But because there may be no god and no will governing human sexual behaviour, it may even be that this argument is wholly $\underset{+}{\stackrel{T}{*}}$ false and serves only indivious human ends. Given these indeterminacies, therefore, I believe that the whole religious thesis of punishment may be set aside $\stackrel{\vec{F}}{\vec{P}}$ as unproved and perhaps unprovable.

\section{MORAL ARGUMENTS}

It is, of course, possible to construct purely $\stackrel{\mathbb{Q}}{\propto}$ philosophical arguments that homosexual behaviour is immoral and on that account deserves AIDS as its punishment. Melik Kaylan, for example, believes that the immorality of homosexual behaviour must $\vec{\omega}$ necessarily have ended in something like the AIDS o epidemic (8). Michael Levin, similarly, believes that AIDS is at least a supporting consideration of why homosexuality is a wrongful abnormality (9). I will $\overrightarrow{+}$ here treat three kinds of moral arguments as they are relevant to pronouncing on the morality of homosexual $\vec{v}$ behaviour. Failure to establish the immorality of $\vec{p}$ homosexual behaviour of course would be a prima facie reason for rejecting the punishment thesis of AIDS.

A. Utilitarian theory. Utilitarian theories assert the $\frac{\mathbb{D}}{\mathbb{O}}$ inherent good of human variability. The pursuit of $\frac{\mathbb{\Phi}}{\overrightarrow{0}}$ truth and the possibility of achieving happiness require $\bar{g}$ allowance for even widely divergent views and $\stackrel{\Phi}{工}$ behaviours (10). Tolerance is of necessity an importanf $\vec{\bullet}$ virtue on such a view.

Wrongful behaviour, under such a view, occus when there is direct involuntary harm to anothe person or where some social good worth preserving is corrupted or lost as the indirect result of people's choices. For example, maiming another person $\stackrel{\square}{\mathbb{D}}$ involuntarily incapacitates that person and therefore, $\varrho$ to a degree proportionate to the harm, may be $\overrightarrow{\overrightarrow{0}}$ controlled and punished. If, to use another example, $\exists$ every adult member of society chose to drug himself or herself into oblivion, even though such behaviour might not involve direct harm to others, still it might be objected to and controlled as it corrupted society in its energy and talent, its art and science, and in its intellectual and moral life.

Under a moral directive of non-interference except in the case of involuntary harm or social corruption, what can be said regarding the immorality of homosexual behaviour?

It seems to me that no convincing argument against homosexual behaviour can be made out along $N$ utilitarian lines. Homosexual behaviour, first of all, $N$ might be seen as part of the variability required in the $\mathrm{N}$ pursuit of truth and happiness. Secondly, among $\omega$ consenting adults, homosexual behaviour is voluntary behaviour that inflicts no harm on others. Thirdly, the presence of homosexual behaviour or persons in a society, even the presence of many such persons, has not been shown to compromise any social ideal. Thus considered, therefore, it seems that a utilitarian argument cannot establish the immorality of $\frac{D}{\infty}$ homosexual behaviour per se. It might be that some $\stackrel{\mathbb{Q}}{2}$ homosexual acts are objectionable but these would be wrong only insofar as they were involuntarily harmful; 
they would not be wrong qua homosexual.

B. Deontological theory. Deontological theories maintain that there are duties binding on all rational agents, duties which may not be abrogated no matter what the circumstances. In a religious deontology, god's commands are to be followed because they are god's commands. Refraining from adultery and theft may or may not make one happy. Happiness is not the point here. Conformity to the will of god is the point whether or not personal happiness follows. In a philosophical form, deontological theory, such as Kant's, claims that there is a moral law that deserves to be revered and respected for the kind of law that it is (11). Following this law may or may not have happy consequences for us, but we are no more free to alter the dictates of morality than we are to alter the rules of arithmetic when we would like more money in our current accounts. The greatest good for human beings is said to be the non-consequential pursuit of the moral law binding on us.

For Kant, the main thrust of the moral law is that we must unconditionally respect the foundations of the worth and dignity of rational beings: autonomy. Lying, for example, is always an assault on dignity because it must necessarily be a manipulation of a rational agent. As a strategy of deception cannot be otherwise, lying is always wrong because to lie is to treat another person like a piece of furniture, moving him or her to positions or behaviours independent of any recognition of the autonomy of the individual.

If a behaviour does compromise respect for rational autonomy, and this is the thrust of the categorical imperative, it must be rejected as immoral, as incompatible with the moral law. It is Kant's position that it is irrational to act on a principle (or maxim) if one cannot will that other rational agents should also act on it. It follows, therefore, that humanity, whether in one's own person or that of another must always be treated as an end in its own right and with its own inviolable integrity. To treat a person as an end means, therefore, never ignoring the person's position as himself or herself, that is, as an independent and rational judge of action.

It is reported in an account of his lectures that Kant did believe homosexual behaviour to be immoral because it contributes nothing to the preservation of the species while debasing the persons involved (12).

It is not obvious though that this conclusion follows from the requirements of the categorical imperative. Homosexual behaviour seems to imply no subjugation of persons that is not precedented in heterosexual behaviour. That is, homosexual behaviour no more involves treating partners as means (and not ends) than heterosexual behaviour. Furthermore, homosexuality by itself is neither evidence of impaired rational capacities nor does it inflict any such consequence on its practitioners (points I will not defend here). It is not obvious either that homosexuality involves a contradiction with other universally desirable traits: truthfulness and charity, for example. It is hard to see too why Kant maintains that openness to reproduction is a condition of sexual morality. Kant's own celibacy contributed nothing to the procreation of the species. How would that celibacy, adopted as universal behaviour, be any less of a threat to the species? There are many goods and goals open to rational beings. If celibate sexuality can serve some morally defensible good, there is no reason to think homosexuality cannot do the same.

Consequently, I conclude that homosexual behaviour is no violation of deontological ethical theory because in itself it neither degrades rational or moral standing of persons nor erects impediments to the pursuit of moral goods.

C. Natural Law theory. Natural Law theories ordinarily argue that existence is ordered towards some state of being. In humans, for example, this order of nature inclines persons toward such things as 1) pursuit of truth, 2) preservation of well-being in mind and body, 3) preservation of the community, and 4) reproduction. Behaviour incompatible with these goals, therefore, is unnatural and immoral: selfstupefaction, murder, and homosexual behaviour, for example. As sexual behaviour, qua homosexual, is inherently sterile, it is incapable of being open to the natural reproductive goals of human beings and is therefore rejected as immoral.

Natural Law theories are often advocated by persons who believe there is a god responsible for the natural order and its achievement of certain goals. As religious arguments have already been treated, I will consider here only a philosophical version of this theory. Under such a view, because of the kind of things humans are, certain behaviours are contrary to the goals towards which nature (read: natural history) inclines them.

The excision of god from such theories, however, seems to disable them considerably. If, after all, there is no god who is both author and enforcer of the natural order, then what normative force remains? What normative force could be invoked for establishing the fixity of sexual behaviour or the inherent worth of certain developmental or natural goals? Surely the history of species adaptation, if understood as the result of blind fate, is no important argument for maintaining that human beings must leave themselves in their lives and behaviours only as evolution has left them. Surely the natural order is not inviolate else we would be left the perpetual victims of disease and natural disaster. If there is no Final Cause by which the world is to be understood, the purpose for which it is made, it seems entirely plausible to say that our sexual behaviour and the rest of our capacities are left to our prudential judgement rather than to the accidents of fate.

All this is to say that if there is no prefixed, normative goal inherent in human life, it is hard to see that homosexual behaviour is any inherent immorality. It may at times be imprudent, but folly is well known in heterosexuality as well. Unless a moral imperative inherent in the 'purposes' of nature is established that 
heterosexual behaviour alone is compatible with ultimate human interests, Natural Law theory cannot show homosexuality to be an inherent immorality.

Consequently, in view of the foregoing discussion, it seems clear that there is no general foundation on which to build an argument that AIDS is a punishment for homosexual behaviour, for it seems that homosexual behaviour as such is not immoral at all. It may be, again, that certain homosexual acts are wrong, sexual acts with children and corpses among them. But behaviours of this kind are not objectionable qua homosexual. Heterosexual behaviours of the same kind would be equally objectionable. Such acts are wrong because they are abusive, demeaning, and endangering. The wrongfulness of such acts is not amplified by their being homosexual in kind. If AIDS is to be understood as a punishment, therefore, one must look beyond homosexuality to find the wrong it redresses.

\section{Even if . . .}

Even if homosexuality could be shown to be an immorality, it is still hard to see why it would deserve AIDS as its punishment. Homosexual behaviour among consenting adults is a victimless crime. It leaves behind no bodies and is no impediment to important social goals. Lethal punishments seem justified, if at all, only in the case of the most serious moral disruptions. Lethal punishments, moreover, are usually attached to behaviours which violate known prohibitions or involve extreme risks. For example, in order to be subject to the most severe criminal penalties, a man who commits murder must be shown to have foreknown the nature and consequences of his action. For the vast majority of persons who have thus far contracted the presumptive causal virus of AIDS, this situation is disanalogous. As Richard Mohr has pointed out, most persons thus far infected contracted the virus at a time when the disease was entirely unknown (13). The murderer either knows or has the means to find out what fate might follow his action. Persons practising homosexual behaviour were not similarly situated.

If AIDS is a new syndrome, its lethal consequences cannot have been foreseen by anyone. Even after the syndrome was identified it remained unpublicised and therefore remained unknown. For example, in the entire first two years of the epidemic in the United States, the New York Times ran a total of three stories on AIDS. By contrast, in the last three months of 1982 (the second year of the epidemic) that same newspaper ran 54 articles on the analgesic Tylenol that had been laced with cyanide. By the time the tainted Tylenol had killed 7 persons, AIDS had already killed 260 (14). As the dangers of AIDS were not foreknown, it is hard to see how they can be said to be deserved. Explorers of oceans, continents and celestial bodies may not foreknow the dangers which lie ahead of them, but it is hard to see how they deserve such harms as might befall them.
One might be tempted to say that it is notm homosexuality per se which offends morality, but that it $\overrightarrow{\bar{*}}$. is promiscuity that opens one up to the punishment of? AIDS. Some homosexual persons, after all, have $\vec{F}$ reported sexual partners in the thousands. Such an argument would parallel the notion of other 'earned'을 diseases. It is not uncommon for persons with $\frac{\bar{\sigma}}{\bar{\rho}}$ emphysema or lung cancer to believe themselves $\overrightarrow{\widetilde{\sigma}}$ reaping the inevitable consequences of their heavy응 smoking habits. Might not AIDS be a punishment in this sense?

Here again, I think the lack of information available on AIDS during the time most persons contracted it $\vec{\omega}$ disallows the comparison. Cigarette smokers are aware, if only in an inchoate way, that heavy smoking is hazardous. Persons engaging in homosexual $\vec{A}$ behaviour might have been aware that they risked ${ }_{\omega}^{\vec{\omega}}$ sexually transmitted diseases, but it is certainly true $\vec{T}$ that they did not foresee anything as deadly as AIDS as $A$ a factor in their risk computations. If the disease is윽 new, the risks cannot have been known. Moreover, it is not promiscuity that spreads this disease. The disease ${ }^{\infty}$ is contracted through behaviour which exposes oneselfo to infected blood or bodily fluids. This may occur in a 3 single sexual encounter. Promiscuity may increase risk of exposure, but by itself promiscuity does not cause exposure. Finally, one may say, too, that if a behaviogr $\vec{\infty}$ is not in itself immoral, as homosexual behaviour does. not seem to be, then engaging in it repeatedly is nto immoral. It seems to me, therefore, that for thes majority of extant AIDS cases and perhaps the majority of AIDS infections, persons are not being punished for their promiscuity or their unnecessary $\underset{\square}{ }$ risk-taking.

\section{Conclusions}

Notions of punishment rely on harm done to invoke justification for harm returned. Because the notion that AIDS is a divine or moral punishment continues toD have currency, I have here reviewed possible rationales: for establishing the immorality of homosexuaf. behaviour. Some religious arguments claim thap homosexuality is both a sin and an immorality. I do nok argue that this position is false, but I do claim that its? premises are not well established and that the religious argument for seeing AIDS as a punishment of homosexuality is incomplete, failing to establish as iț does why god has only now chosen to punish the homosexuality of only some persons and why he hass done so with such vehemence. I claim that because of the indeterminacies of religious arguments generalls and because of the incompleteness of this religious argument in particular, the divine punishment thesi\$s may be set aside as unconvincing. Purely moraf arguments, I claim further, fail to establish thaț homosexual behaviour is an immorality. Utilitarian $\frac{\mathrm{D}}{\mathrm{D}}$ deontological, and Natural Law theories either fail tథ show homosexual behaviour as an impediment t\& important moral goals or, where they might be used tQ condemn homosexual behaviour, fail to be themselves 
well-established. Moral arguments from these kinds of theories fail to demonstrate that homosexual acts must necessarily involve involuntary harm to others, compromise the existence of social goods, or compromise the rational autonomy that is the foundation of human worth and dignity. The singular failing of Natural Law theory is that it fails to establish a normative basis for excluding homosexuality from the sexual practices of human beings. Additionally, important questions regarding the proportionality between homosexual behaviour and its putative punishment and regarding the extent to which the disease is 'earned' weaken the thesis that AIDS is a just punishment. I conclude therefore that the notion of AIDS as a just punishment of homosexual behaviour is intellectually indefensible and even a malicious theory. To the extent that this theory holds sway, moreover, it can prove an impediment to medical attempts to prevent, treat, and cure AIDS. I would suggest that there are more moral lessons to be learned from how people respond to AIDS than from how they contract it.

Timothy F Murphy PhD is Assistant Professor of the Biomedical Sciences at the University of Illinois at Chicago, 808 South Wood St, Chicago, IL 60612, USA.

\section{References}

(1) Congregation for the Doctrine of the Faith. Letter to the bishops of the Catholic Church on the pastoral care of homosexual persons. Washington: United States Catholic Conference, 1986: 7.

(2) Thomas C. Preventing the spread of AIDS. The Boston Globe 1985 Aug 1: 15.

(3) Leuken V. Roses. Our Lady of the roses. Flushing Meadow Park, Bayside, New York: 1985 Aug 21.

(4) Ross J W. Ethics and the language of AIDS. In: Pierce $\mathrm{C}$, VanDeVeer D, eds. AIDS, ethics and public policy. Belmont, CA: Wadsworth, 1988: 41.

(5) Bradlee B. Life and struggle in the AIDS ward. The Boston Globe 1985 Apr 4:2.

(6) White A D. A history of the warfare of science with theology in Christendom. New York: Free Press, 1965: 291-294.

(7) Kopelman L. The punishment concept of disease. In: White C, VanDeVeer D, eds. AIDS, ethics and public policy. Belmont CA: Wadsworth, 1988: 49-55.

(8) Kaylin M. Destruction of Sodom. The Spectator 1986 Apr 12: 18-20.

(9) Levin M. Why homosexuality is abnormal. Monist 1985 ; Spring: 251-283.

(10) Mill J S. On liberty. Boston: Ticknor and Fields, 1863. Utilitarianism. New York: Liberal Arts Press, 1953.

(11) Kant I. Foundations of the metaphysics of morals. New York: Liberal Arts Press, 1959.

(12) Kant I. Lectures on ethics. New York: Harper and Row, 1963:70.

(13) Mohr R. AIDS, gay life and state coercion. Raritan 1986; VI: 38-62.

(14) Shilts R. And the band played on. New York: St Martin's Press, 1987: 191, 268. 